\title{
Amava am kumhlangano eCalders Hotel: Reflection of the Workshop
}

\author{
Bongeka Mhlauli \\ University of the Western Cape
}

Njengomfundi okweli nqan aba ndifunde lukhulu kumhlangano. Okokuqala nanjengokuba ndisemtsha apha, ukuthatha okanye ukubhala iingcinga zakho kuye ngamanye amaxesha kubenzima. Apha ufumanisa ukuba ininzi imiba esengqondweni yakho, loo nto ibangele ukuba uxakwe yindlela yokuyibhala phantsi.

Iindibano ezinje ngezi ziluncedo kakhulu ingakumbi kubabhali abasaqalayo kanti nakwabo sele bebalasele. Injongo yendibano kukuphuhlisana phakathi kwabo babhalayo okanye benza uphando kulwimi nakuyo nantoni na engenye.

Kusuku lokuqala: apha ngumhla esafika ngawo kwindawo apho sasizobambela khona indibano sileli qela. Apha sahlala iintsuku ezintathu simane ukuchitha imini yonke kwigumbi elithile apho iindibano zibanjwa khona. Ngolu usuku kwakugxilwe kumba wokubhala ithesis. Kwakujongwa ekubeni zinto zini ezingakunceda njengomfundi okweli nqanaba lokubhala uphando. Apha abantu bathetha ngamava abo kolu hambo lokubhala uphando. Kule ndibano bekudibene abantu abakumanqanaba ahlukeneyo, bakhona abo bakwinqanaba leMasters, Phd abanye sele bezingcali(Professors). Ndiye ndafumanisa ukuba wonke ubani apha unalo ibali lakhe lokubalisa, kwaye sonke sidibene nazo iingxaki xa besibhala.
Xa ubhala uphando lwakho kufuneka ulubhale ngononophelo kuba kufuneka lupapashiwe. Le nkcazo yathi yenziwa nguDr Q.Williams osuka kwicandelo le Linguistics. Xa into iza kupapashwa eluntwini kufuneka ibe kwinqanaba eliphezulu ukuze ikwazi nokuphuhla injongo yophando lwakho. Abantu bafunda into enika emdla. Oku kuthetha ukuba umphandi okanye umfundi kufuneka awubhale ngononophelo olukhulu umsebenzi wakhe. Kubalulekile ukuba uhambe ufuna uncedo nakwabanye xa ubhala. Abo bantu isenokuba ngabantu abakwinqanaba elinye nawe okanye abakwinqanaba eliphezulu kunawe. Loo nto iyanceda ukuze ukwazi ukumelana neengxaki ezithi zivele xa ubhala. UDr usibonise iindlela ezithile esinokuthi sibhale ngazo okanye sizisebenzise ukuze sikwazi ukubhala uphando olusemgangathweni.

UDr A, Peck naye uye wasibalisela ngeengxaki okanye amahla ndinyuka adibane nawo xa wayebhala phando lwakhe. "kukho ixesha apho umsebenzi wam wawumana ukubuyiswa oko ukuba ndiwenze kwakhona, kodwa ndandizixelele ukuba ndiwubhale ngendlela. Apha ndaxelelwa ukuba ndenze lento kuthiwa yi self plagiarism. Oko kuthetha ukuba iingcinga zam azibonakali njengezi zezam." Ukukhuphela iingcinga zomnye umntu 
uze ungamchazi yinto ebonakalisa ukungathembeki komntu lowo ubhalayo. Lo nto yenza ukuba umsebenzi wakho ungathathelwa ngqalelo kwaye loo nto ingakufaka engxakini njengombhali. Amaziko emfundo awakuvumeli oku ingakumbi xa ukweli nqanaba.

Usuku lwesibini nalo belunika umdla kakhulu. Ngalo umhla abafundi babehleli kunye nabacebisi babo okanye abafundisi babo. Injongo yaye ikukuba babonise imisebenzi esele beyibhalile ukuze balungiswe kunye nokucetyiswa ngakumbi. Abafundisi aba bona umsebenzi wabo yaye ikukujonga inkqubela yomfundi ukuze abenako nokubuza imibuzo ethile xa kukho imfuneko. Babekhona nabafundisi ababesenza iingxelo kwimiba ngemiba abenze kuyo uphando enxulumene nolwimi. uProfessor Kell waye engomnye wabo kunye noDr Zannie Bock. Apha umntu ngamnye waye enika ingxelo ngezinto ezibalulekileyo nathe wazifumana xa ebesenza uphando. Olu yayilusuku olude kakhulu.

uProfessor Kell kwisifundo sakhe ubonakalise izinto ezininzi. Uye waveza neengxaki ezininzi ezingqonge uphando kwizifundo. Apha kubonkala ngathi ininzi into efuna ukwenziwa, babonakala bembalwa abantu abaphandayo kwinqanaba eliphezulu lemfundo ingakumbi kumazwe athile. Uzivezile neengxelo ezibonisa oko. Oku kwaye kwanika umdla noxa kumangalisa nje, kwabonisa ukuba sinoxanduva olukhulu lokuphucula indlela esenza ngalo uphando lwethu. Kufuneka sinyuse iikawusi.

Usuku lwesithathu yaye ilusuku lokuqukumbela. Apha izithethi zaqukumbela zigxininisa kakhulu kukubaluleka kweendibano. Apha kwaxoxwa nangemiba yokuba ingaguqulwa njani ithesis ibeyincwadi. Lo mba yayingumba omtsha apha kwaye wawusaza kuqwalaselwa kwixa elizayo. Kodwa ke imibuzo eyathi yavela yaye yaphendulwa. UProfessor Stroud nguye owaye equkumbela esiza nemiba engathi incede ekubeni kwenziwe olu guqulo. Uye wasixelela nangawakhe amava nangabantu abathile abakhe babhala izinto ezilolu hlobo. Sileli qela siye saxoxa ngeendlela ezinokuthi zisincede sihlale sisabelana ngolwazi. Siye sacebisana ngeendlela ngeendlela esinothi simane sizenza sizame ukudibana. Emva kwayo yonke into umntu ngamnye waye wanikwa umsebenzi amaze awenze. Le misebenzi yohlukile ngokwendlela okanye amanqanaba esikuwo. Injongo ibe kukujonga ukuba ngaba le ndibano ibe yimpumelelo kusini na.

Emva kwayoyonkeinto eyayiqhubeka eCalders ndaziva ndihlaziyekile ngokwasengqondweni. Ndaziva ndikulungele ukuqalisa nokubhala uphando lwam. Ndasele ndizibona iindlela endinothi ndizibhale ngayo iingcinga zam phantsi. Ndakonwabela kakhulu ukuba yinxalenye yalo ndibano.

\section{REFLECTION OF THE WORKSHOP}

As a new research student, I have learnt lot in the workshop. Firstly as a new candidate in the research world it is sometimes difficult to put your ideas in to writing. In this case you will find that you have so many ideas in your head and that makes it difficult to write them down.

Workshops like these are very helpful especially to those researchers who are at an early stages of their research. It is also helpful even to those who are professionals. The aim of a workshop or meeting among a group of people is to develop each other ideas. Here people share their ideas and get help. 
The first day: this was the day of our arrival as a group at Calder's Hotel in Fischoek. We were going to spend three consecutive days there. We spent each day in a seminar room where meetings are held. On this day the focus was on how to write a thesis successfully. It was specifically looked at things that can help you as a student who is at this level of her or his research. Here people expressed their views and shared their experiences in the journey of writing. In this workshop we were from different levels, there were Masters Students, $\mathrm{PhD}$ and also those who are experts already the professors. I had found out that everyone had something to tell regarding his writing and everyone had experienced problems.

When writing your research, it must be in good quality for publishing. One must be very careful and focused when writing her thesis because the public might not be interested or pay attention in her work.

When writing your thesis $\mathrm{u}$ need to pay more attention as it is going to be published. The information on publishing was given by Dr Williams from the Linguistics Department. When a study is going to be published in the public, it needs to be in high standards so that the aim of it can come out. People read interesting work. This means that a writer must be on top of his game. It is important to seek for help from others when writing. They may be on the same level as you or in higher level than yours. This helps to be able to face challenges that might appear during the process of writing. Dr Williams presented ways in which we can use to pursue our studies so that our studies can be in high standards.

Dr Peck also told us about her challenges or ups and downs during the time she was persuading her doctorate studies. "There was a time where my work was returned to be done again, but I told myself that I had done my best. Here I was told that I did self-plagiarism. This means that my ideas were not seen s original. Using another person's ideas and not acknowledge her or him is a serious offence. It shows untrustworthy to the person writing. This makes your work not to be given any attention as a researcher. Higher insitutions do not allow plagiarism especially to researchers at this level.

The second day was also very interesting. On this day students were discussing with their supervisors. The aim was to show their work to the supervisors and be advised or helped further by their supervisors. The supervisor's task was to look at the work of their students and allow them to ask questions when necessary. There were also professors who made presentations on different topics in which they made research on, especially in linguistics. Professor Kell was one of the presenters and Dr Zannie Bock. In this case each person presented her work on important issues that she overcome during her research study. This was a very long day.

Professor Kell in her study showed a lot of things. She also showed challenges that are facing language researchers. It seemed as if there is a lot of work that needs to be done, researchers seemed to be very few especially at higher levels in some other countries. She also showed evidence in supporting the above reports. The reports were very interesting although they were shocking, it showed that we are faced with responsibility of improving our researches. We need to be committed to our work and work hard.

Third day was the day of concluding everything. On this day the speakers or presenters emphasized on the importance of a meeting. The discussion was on issues of changing a thesis into 
a book. This issue was still new on the agenda and was going to be given much thought in the future. Questions related to this issue were asked and professor answered them. Professor Stroud was the one who concluded everything. He also brought suggestions on what can be done in relation to the above mentioned issue. He also told us about his experiences and those of others who did a similar thing. As a group we discussed ways in which we can keep meeting each other. In conclusion everyone was given a task to do. These tasks were different according to our levels. The aim was to see whether the workshop was successful or not.

After everything had been concluded at Calders Hotel, I felt so thankful and relaxed in mind. I felt ready to start writing my thesis. I had developed some ideas on how I can write

It. I enjoyed my time there. I had a very productive three days in the Workshop and my fears were addressed carefully. I am looking forward to the next meeting with the group. I am very grateful to Center for Multilingualism and Diversity Research. 